\title{
Kadın Doğum Kliniğinde Çalışan Hemşire ve Ebelerin Doğum Sonu Dönemde Hastalara Bakım Verirken Yaşadığı Zorluklara İlişkin Görüşleri: Kalitatif Çalışma
}

\section{Opinions of Nurses and Midwives Working in the Obstetrics Clinic Regarding The Difficulties Experienced While Giving Care to The Patients in the Postpartum Period: Qualitative Study}

\author{
Nurcan Kırca ${ }^{1}$ \\ ${ }^{1}$ Akdeniz Üniversitesi Hemşirelik Fakültesi, Doğum ve Kadın Hastalıkları Hemşireliği, Antalya, TÜRKIYYE
}

Geliş tarihi/ Date of receipt: 15/05/2020

Kabul tarihi/ Date of acceptance: 22/09/2020

(C) Ordu University Faculty of Health Sciences, Department of Nursing, TURKEY, Published online 30/09/2020

\begin{abstract}
ÖZ
Amaç: Bu çalışmada amaç, kadın doğum kliniğinde çalışan hemşire ve ebelerin doğum sonu dönemde hastalara bakım verirken yaşadığı zorluklara ilişkin görüşlerini incelemektir.

Yöntem: Nitel araştırma yöntemi ile yürütülen çalışmada fenomenolojik desen kullanılmıştır. Çalışma grubu, Türkiye'de bir kamu hastanesinde kadın doğum kliniğinde çalışan hemşire $(n=7)$ ve ebelerden $(n=2)$ oluşmuştur. Veriler; Şubat-Mart 2020 tarihleri arasında bireysel ve odak grup görüşmesi ile toplanmış ve içerik analizi yöntemi ile çözümlenmiştir.

Bulgular: Katılımcıların sosyodemografik özellikleri değerlendirildiğinde; yaş ortalamasının 39.21 \pm 9.58 , çalışma yılının $16.12 \pm 8.61$, kadın doğum kliniğinde çalışma süresinin $13.17 \pm 4.61$ y1l olduğu saptanmıştır. Hemşire ve ebelerin \%88.8'inin evli, tamamının doğum yaptığı ve üniversite düzeyinde eğitim aldı ̆̆ı saptanmıștır. Analiz sonucunda elde edilen temalar; "kadın doğum kliniğinde çalışan hemşire ve ebe olmayı tanımlama", "kadınlara bakım verirken yaşanılan zorluk", "katılımcıların yaşanılan zorluklar ile baş etme yöntemleri" ve "çözüm önerileri" dir.

Sonuç: Hemşirelerin doğum sonu dönemde bakım verirken emzirmede zorlanma, iletişim sorunu, kültürel farklılıklar gibi zorluklarının olduğu ve bu zorlukların ortadan kaldırılmasına ilişkin bazı önerileri sunduğu belirlenmiş̧ir.

Anahtar Kelimeler: Doğum sonu bakım, ebelik, fenomenoloji, hemşirelik
\end{abstract}

\begin{abstract}
Objective: The aim of this study is to examine the views and experiences of nurses and midwives working in the obstetrics clinic the obststrics clinic regarding the difficulties they experience while providing care to patients in the postpartum period.

Method: In the study carried out with qualitative research method, phenomenological pattern was used. The working group, working in a public hospital obstetrics nurse in Turkey $(n=7)$ and midwives $(n=2)$ was formed. Data; It was collected between February and March 2020 by individual and focus group meetings and analyzed by content analysis method.

Results: When the sociodemographic characteristics of the participants are evaluated; the mean age of the patients was $39.21 \pm 9.58$, the working year was $16.12 \pm 8.61$, and the working period in the obstetrics clinic was $13.17 \pm 4.61$ years. It was determined that $88.8 \%$ of the nurses and midwives were married, all gave birth and received education at university level. Themes obtained as a result of the analysis; "Defining being a nurse and midwife working in the obstetrics clinic", "difficulty in giving care to women", "methods of coping with the difficulties experienced by the participants" and "solution suggestions".

Conclusion: It was determined that the nurses offered some suggestions for the elimination of these difficulties, which they had difficulties in breastfeeding, communication problems, and cultural differences while providing care in the postpartum period.

Keywords: Postpartum care, midwifery, phenomenology, nursing
\end{abstract}

ORCID IDs of the authors: NK: 0000-0003-1856-4026S

Sorumlu yazar/Corresponding author: Dr. Öğr. Üyesi Nurcan Kırca

Akdeniz Üniversitesi Hemşirelik Fakültesi, Doğum ve Kadın Hastalıkları Hemşireliği, Antalya, TÜRKIYE

e-posta/e-mail: nurcan1224@gmail.com

Atıf/Citation: Kırca N. (2020). Kadın doğum kliniğinde çalışan hemşire ve ebelerin doğum sonu dönemde hastalara bakım verirken yaşadığı zorluklara ilişkin görüşleri: Kalitatif çalışma. Ordu Üniversitesi Hemşirelik Çalışmaları Dergisi, 3(2), 59-71.

DOI:10.38108/ouhch.737857 


\section{Giriş}

Postpartum dönem, plasentanın doğumu ile başlayıp ve doğum sonrası 6-12 haftayı içeren bir süreci kapsamaktadır (Taşkın, 2016). Bu dönem içerisinde laktasyonun devamlılığ 1 için memeler hariç diğer sistemlerde ve üreme sistemine ait organlarda gerileyici (retrogresif) değişimler meydana gelmektedir. $\mathrm{Bu}$ değişimler ilk iki hafta içerisinde çok hızlı bir şekilde gerçekleşmektedir (Aslan, 2015; Taşkın, 2016). Doğum sonu dönemde meydana gelen bu değişimler; involusyon, rejenerasyon ve laktasyon şeklinde gruplandırılmaktadır (Taşkın, 2016). Bu değişimler göz önüne alındığında doğum sonu dönem, anne ve bebek için hemşirelik bakımına çok fazla ihtiyacın olduğu bir dönem olarak görülmektedir. $\mathrm{Bu}$ dönemde basit sorunların çözümünde bile güçlükler yaşanabilmektedir ve aile yardıma ihtiyaç duyabilmektedir. $\mathrm{Bu}$ sebeple doğum sonu dönemdeki hemşirelik bakımı anne ve yenidoğanın ihtiyaçlarını karşılayacak şekilde planlanmalıdır (Güneri, 2013; Taşkın, 2016). Hemşire/ebenin bu aşamada rolü çok önemlidir. Bakım vermek için gerekli bilginin kalitesi bütüncül bakım anlayıșını gerektirir ve bu klinik ve teknik bilgiden daha geniş bir kavramdır (Bonis, 2009; Chinn ve Kramer, 2015). Hemşirelik bakımının kalitesi, kadınların doğum algısını ve hemşirelik bakımindan memnuniyetlerini de olumlu yönde etkilemektedir (Y1lmaz ve Nazik, 2018). Doğum eylemi sirasında ve doğum sonu dönemde hemşirelerin birey merkezli olarak, anne ve bebek bakımını birebir karşılamalarının annenin bakım memnuniyetini arttırdığ 1 ifade edilmektedir (Alp-Yılmaz ve Başer, 2017). Ancak yapılan başka bir çalışmada annelerin yeterli ebelik/hemşirelik bakımı almamalarına karşın verilen bakımdan memnun olduklarını ifade ettikleri saptanmıştır (Arslan-Gürcüoğlu ve Vural, 2018). Bu sebeple doğum sonu kliniklerde annelerin beklentileri ve bakım memnuniyetleri arasındaki ilişki üzerine daha fazla çalışmaya ihtiyaç duyulduğu belirlenmiştir (ArslanGürcüoğlu ve Vural, 2018). Doğum sonu dönemde annenin ve hemşire/ebelerin öncelikleri benzer olsa da doğum sonu anne eğitiminde önceliklerin siralaması değişebilmektedir. Doğum sonu dönemde hemşireler/ebeler yenidoğan beslenmesine öncelik verirken, anneler genellikle bebeklerinin hastalıklarına öncelik vermektedirler. $\mathrm{Bu}$ bağlamda hemşire ve ebelerin, doğum sonu dönemdeki kadının beklentileri ve önceliklerinin farkına varabilme konusundaki farkındalıklarının arttırılması önem taşımaktadır. Ebelere verilen empati eğitiminin, doğum sonu dönemdeki annelerin beklentilerini karşılama, doğumu ve ebeyi algilamaya olan etkisinin değerlendirildiği bir çalışmada; didaktik anlatım, psikodrama gibi empati eğitimlerinin olumlu etkisinin olduğu görülmüştür. Ebelere verilen empati eğitimi sonrasında doğum yapan annelerin doğum ve ebeye yönelik algılarının olumlu yönde artış gösterdiği belirlenmiştir (Aktaş ve Pasinlioğlu, 2017). Hemşire/ebenin empati becerisinin gelişmiş olması, doğum öncesi dönemdeki kadınların doğuma yönelik algılarının olumlu yönde değişmesine fayda sağlayabilir (Berg ve ark., 2012; Hatem ve ark., 2008). Hemşire/ebenin empatik yaklaşımı, kadınların normal vajinal doğuma yönelik endişelerinin azalmasını sağlayarak, sezaryen oranlarının düşürülmesinde etkili olabileceği belirtilmektedir (Berg ve ark., 2012; Hatem ve ark., 2008). Bu sebeple annelere eğitim ve doğum sonu bakım verirken annenin önceliklerinin de dikkate alınması önemlidir (Altuntuğ ve Acar, 2011). Ayrica doğum öncesi ve doğum sonrası annelere verilen eğitim ile annelerin doğum sonu dönemde güçlük yaşama durumlarının azaldığı, taburculuğa hazır oluşluk düzeylerinin ve yaşam kalitelerinin arttığı bildirilmiştir (Altuntuğ ve Ege, 2013).

Dünya Sağlık Örgütü (DSÖ)'nün verilerine göre; Dünya genelinde kadınların \%72'si, doktor veya hemşire/ebe gibi deneyimli bir sağlık personelinin yardımı ile doğum yapmaktadır. $\mathrm{Bu}$ oran Güneydoğu Asya'da \%67 ve Sahra altı Afrika'da ise \%48'dir. Sahra altı Afrika ülkelerinde, evde doğum yapan kadınların sadece \%13'ünün doğumdan sonraki ilk iki gün içinde doğum sonrası bakım alabildiği belirtilmiştir (WHO, 2015). Türkiye 
Nüfus ve Sağlık Araştırması (TNSA) 2013 verilerine göre Türkiye'de, kadınların \%97'si en az bir kez doktor veya hemşire/ebe gibi sağlık personelinden doğum öncesi bakım almıştır. Doğum sonu dönemde; kadınların \%73,9'u doğumu takiben ilk dört saat içinde, $\% 93,1$ 'i ise doğumdan sonra ilk 41 gün içinde sağlık personelinden doğum sonu bakım almıştır (TNSA, 2013). TNSA 2018 sonuçlarına baktığımızda ise annelerin \%96'sı doğum öncesinde sağlik personelinden bakım almıştır. Doğum sonu dönemde ise; annelerin \%66's1 doğumu takip eden ilk dört saat içinde, $\% 83,4$ 'ü doğumdan sonra ilk iki günde sağlı personelinden doğum sonrası bakımı almıştır (TNSA, 2018). Her iki araştırmanın verileri karşılaştırıldığında doğum sonu dönemde, en az bir kez doktor veya hemşire/ebe gibi sağlık personelinden bakım alan kadınların oranında önemli bir farklılık bulunmaz iken, doğum sonu ilk dört saat içinde bakım alan kadınların say1s1 \%73,9'dan \%66'ya gerilemiştir. Benzer sonuçlar yenidoğan bakımı ile ilgili verilerde de görülmektedir. TNSA 2013 verilerine göre yenidoğan bebeklerin ise \%40,9'u ilk bir saat içinde, \%93,7'si doğumdan sonra 41 gün içinde sağlık personelinden doğum sonrası bakımı almıştır (TNSA, 2013). TNSA 2018 verilerine göre ise yenidoğan bebeklerin $\% 36,7$ 'si doğumdan sonra ilk bir saat içinde, $\% 68$ 'i ise doğum sonrası ilk iki gün içinde sağlık personelinden doğum sonrası bakım aldığ 1 belirlenmiştir (TNSA 2018).

Antenatal dönemde bakım alınmaması sağlik hizmetlerine uyumu olumsuz etkileyerek bakım veren hemşire ve bakım alıcı kadın arasındaki ilişkiyi olumsuz etkilemektedir. Anne ve hemşire/ebe arasındaki ilişkiyi etkileyen en önemli etmen dil engelidir (Goodwin ve ark., 2015). Özellikle intrapartum süreçte iletişim kurulamaması anne ile hemşire/ebe arasında güvensizliğe neden olarak doğumun uzamasina ya da olumsuz sonuçlanmasina neden olabilmektedir (Akhavan ve ark., 2012). Sağlık hizmetleri ve kültürel farklılıkların birbirine entegrasyonunun sağlanamaması (ayakta doğum, doğumda kadının istediği birinden destek alması vb.) annenin bakımı reddetmesine neden olabilmektedir. Doğumda kurum kültürü ve ülke sağlık politikaları nedeniyle hemşire, annenin kültürel uygulamalarını gerçekleştirmesine izin verememektedir. Bu durumda; anne bakımı red ederken, hemşire/ebe kendini güvene almakta, arada güvensizlik ve iletişim problemi yaşanmaktadır (Cioffi, 2004). Yaşanan bu olumsuz durumlar doğumda yeterli desteğin verilmesine engel olarak anne ve fetüsü strese sokmakta ve doğumun uzamasina neden olmaktadır. $\mathrm{Bu}$ nedenle hemşire bakım verdiği annenin kültürel, dini, sosyo-ekonomik farklılıklarını göz önünde bulundurmalı, ayrımcılık yapmadan bakım vermeli ve danışmanlık yapmalıdır (Goodwin ve ark., 2015). Farkl1 kültürlerden olan göçmen kadınlara bakım verilirken dil engeli ile karşılaş1labilmektedir. $\mathrm{Bu}$ nedenle; bakımın devamlılığı için hemşire-anne arasındaki iletişiminin devamlılığının ve etkinliğinin sağlanması ve dil farklılığı gibi iletişim güçlügüne neden olan durumları çözümleyebilmek amaciyla da sağlık kuruluşlarında bir tercümanın bulunması gerekmektedir (Akhavan ve Lundgren, 2012). $\mathrm{Bu}$ sebeple doğum sonu bakımın sürdürülebilir olması da önem taşımaktadır. $\mathrm{Bu}$ yönden ele alındığında doğum sonu bakımın devamlılığ konusunda yeterince veriye ulaşılamamıştır. Doğum sonu dönemde hemşire ve ebelerin bakım verirken yaşadığı güçlüklere ilişkin çalışmalar sınırlı sayıdadır. Türkiye'de ise böyle bir çalışmaya rastlanmamıştır.

$\mathrm{Bu}$ çalışma, kadın doğum kliniğinde çalışan hemşire ve ebelerin doğum sonu dönemde hastalara bakım verirken yaşadıkları zorluklara ilişkin deneyimlerini tanımlamak amacıyla yapılmıştır.

\section{Yöntem}

\section{Araştırmanın Türü}

$\mathrm{Bu}$ çalışmada nitel araştırma yöntemlerinden olgu bilim (fenomenoloji) yöntemi kullanılmıştır. Olgu bilim, yaşanmış bir olayı açıklamada kullanılan, insan deneyimlerini anlamayı kolaylaştıran tümevarımsal ve açıklayıcı bir yöntemdir. Olgu bilim deseni, araştırılan olgudan bilgi elde 
etmek için katılımcıların deneyimlerinden yararlanan nitel araştırma yöntemlerinden biridir (Yıldırım ve Şimşek, 2016). Olgu bilim deseni doğası gereği amaçlı rastgele örnekleme yöntemini kullanmaktadır. Amaçlı rastgele örnekleme araştırmanın amacı doğrultusunda nedeni belli olan olgu ile ilgili zengin bilgi elde edilebilecek katılımcılardan oluşmaktadır (Baltacı, 2018; Yıldırım ve Şimşek, 2016).

\section{Evren ve Örneklem}

Araştırmanın örneklemini, Sağlık Bakanlığına bağlı bir devlet hastanesinin kadın doğum kliniğinde çalışan 11 hemşire ve ebe oluşturmaktadır. İki hemşirenin raporlu olmasından dolayı araştırma 9 katılımcı ile yürütülmüştür. Bunlardan 7'si hemşire 2'si ebedir.

\section{Araștırmanın Yeri ve Zamanı}

Araştırma Türkiye'de bir devlet hastanesinin kadın doğum kliniğinde yapılmıştır. Görüşmeler Şubat-Mart 2020 tarihleri arasında yapılmıştır. Araştırmada amaçlı örnekleme yöntemi kullanılmıştır.

\section{Veri Toplama Yöntemi ve Araçları}

Araştırmacı tarafindan hemşire ve ebelerin deneyimlerini belirlemeye yönelik açık uçlu ve yarı yapılandırılmış sorular hazırlanmıştır. Yarı yapilandırılmış yöntem, araştırmacıya çalışmada esneklik ve özgürlük sağladığ 1 için seçilmiştir. $\mathrm{Bu}$ yöntemin diğer bir yararı ise, katılımcıları cesaretlendirmek için serbest soru sorma özgürlüğü vermesidir (Erdoğan, 2014). Görüşme formunda yer alan soruların oluşturulmasında literatür dikkate alınmıştır (Macdonald ve ark. 2019, Puia ve ark 2013) Görüşme formu doğum sonu dönemde bakım veren hemşire ve ebe olmayı tanımlama, bakım verirken yaşadığ 1 sorunlar, bu sorunlarla nasıl baş ettikleri, sorunlara ilişkin çözüm önerileri ve bu klinikte çalışan bir hemşire ve ebeyi neye benzettiği, benzetme nedeninizi bizimle paylaşır mısınız? şeklinde beş sorudan oluşmaktadır. Görüşme sırasında sondaj sorular da sorulmuştur. Görüşmelerin kaydedilmesi için hemşire ve ebelerden izin alınarak ses kayıt cihazı kullanılmıştır. Ayrıca hemşire ve ebelerin sosyo-demografik verilerini içeren demografik soru formu ve aydınlatılmış onam kullanılmıştır. Demografik soru formu yaş, eğitim, meslek, medeni durum, çocuğunun olup olmaması, gelir durumu, daha önce başka klinikte çalışma durumu, kadın doğum kliniğinde çalışma süresi ile ilgili sekiz sorudan oluşmaktadır. Bireysel ve odak grup görüşmelerinde aynı sorular sorulmuştur. Bireysel görüşme formuna ayrıca bir tane metafor sorusu eklenmiştir.

\section{Veri Toplama Süreci}

Veriler bireysel ve odak grup görüşmesi yöntemi ile toplanmıştır. Hemşire ve ebelerden randevu alınarak uygun oldukları gün ve saatte bireysel ve odak grup görüşmeleri planlanmıştır. Dokuz katılımcı ile 3-19 Şubat 2020 tarihleri arasinda önce bireysel görüşmeler yapılmıştır. Daha sonra katılımcılar üç gruba ayrılıp 24 Şubat-06 Mart 2020 tarihleri arasında üç odak grup görüşmesi yapılarak veriler toplanmıştır. Soru sorma ve yanıtlama şeklinde iletişim süreci şeklinde olan "Derinlemesine Görüşme Yöntemi" kullanılmıştır (Şimşek ve Yıldırım, 2006). Görüşmeler hastanede özel bir odada yapılmıştır. Görüşmenin tamamı araştırmacı tarafından yapılmıştır. Görüşmeye başlamadan görüşmecilere aydınlatılmış onam okunmuş ve bilgi toplamak için görüşmecilerin izni alınarak ses kaydı yapılmıştır. Görüşmeler ortalama 50 dakika sürmüştür.

\section{Verilerin Analizi ve Değerlendirmesi}

Verilerin analiz edilmesi aşamasında Nvivo 10 paket programı kullanılmıştır. Ses kayıt cihazına araştırmacı tarafından kaydedilen görüşmeler bilgisayar ortamında hazırlanan forma aktarılmıştır. Görüşme yolu ile elde edilen araştırma verileri, içerik analizi yöntemiyle incelenmiştir. İçerik analizi verilerin dökümü, verilerin kodlanması, verilerin sinıflandırması ve verilerin ilişkilendirilmesinden oluşmaktadır (Erdoğan, 2014). Ses kaydından elde edilen veriler bilgisayar ortamına aktarılarak raporlanıp ve kodlanmıştır. Daha sonra kategoriler oluşturularak çözümlemeler yapılmıştır. Aynı anlama gelen kelimeler sınıflandırılmıştır.

Araştırmanın iç geçerliğini artırmak için bireysel ve odak grup görüşmesi yapılmıştır. (Zengin, 2007). İçerik analizinde temalar oluşturulmuştur. Temaları oluşturan alt 
temaların kendi aralarındaki ilişkisi ile her bir temanın diğerleriyle ilişkisi kontrol edilerek bütünlük sağlanmıştır. Temalar oluşturulmuştur ve bu temaların da altında alt temalar oluşturulup veriler analiz edilmiştir. Araştırmanın iç güvenirliğini (tutarlık) sağlamak için bulguların tamamı yorum yapılmadan doğrudan verilmiştir. Ayrıca görüşmede elde edilen veriler üzerinde araştırmacı ve nitel araştırma konusunda deneyimli iki öğretim üyesi ayrı ayrı kodlamalar yapmıştır. Araştırma verileri hemşirelik alanında nitel çalışma yapmış iki araştırmacı tarafından farklı zamanlarda değerlendirilmiştir. Tutarlılık oranı değerlendirme için Cohen's Kappa istatistiği kullanılmıştır (Kappa: .824;p<0.000). Buradan yapılan değerlendirmelerin güvenirliğinin çok yüksek olduğu belirlenmiştir (Bıkmaz Bilgen ve Doğan, 2017). Kohen Kappa katsayısının $<0,0$ olması uyumun olmadığını, 0,0 ile 0,20 arasında olması çok az düzeyde uyumun olduğunu, 0,21 ile 0,40 arasında olması az düzeyde bir uyumun olduğunu, 0,41 ile 0,60 arasında olması orta düzeyde bir uyumun olduğunu, 0,61 ile 0,80 arasında olması önemli düzeyde bir uyumun olduğunu, 0,81 ile 1,00 arasında olması ise mükemmel bir uyumun olduğu şeklinde yorumlanmaktadır (Yiğitbaş ve Yetkin 2003). Bu araştırmada araştırmacılar arasında mükemmel bir uyum olduğuna ve kodlamanın güvenilir olduğuna karar verilmiştir. Araştırmanın diş güvenirliğini artırmak için veri toplama araçları, ham veriler, analiz aşamasında yapılan kodlamalar ve rapora temel oluşturan algılar dişarıdan bir uzmanın incelemesine sunarak teyit incelemesi yaptırılmıştır.

\section{Araştırmanın Etik Boyutu}

Araştırma yapılmadan önce etik kurul onayı (Tarih: 08.01.2020/ Karar No: 64) ve hastaneden de kurum izni alınmıştır. Araştırma Helsinki Bildirgesi'nin kurallarına uyularak yapılmıştır. Ayrıca katılımcılara araştırmanın adı, amacı, süresi ve şekli hakkında bilgi verilmiştir. Görüşmeden elde edilecek verilerin daha iyi anlaşılması için araştırmanın kaydedileceği açıklanmıştır. Katılımcıların araştırmaya katılımlarının gönüllülük esasına dayalı olduğu, isimlerinin kesinlikle geçmeyeceği söylenmiştir. Araştırmaya katılan hemşire ve ebeler $\mathrm{K} 1, \mathrm{~K} 2, \mathrm{~K} 3, \ldots$ şeklinde kodlanmıştır. Katılımcılardan K2, K3, K4, K5, $\mathrm{K} 6, \mathrm{~K} 7$ ve $\mathrm{K} 8$ hemşire olup $\mathrm{K} 1$ ve $\mathrm{K} 9$ ise ebedir. Katılımcılar araştırmaya gönüllü olarak katılacaklarını ifade ettikten sonra araştırmaya katılım formunu okuyup imzalamaları istenmiştir.

\section{Bulgular}

Kat1lımc1ların sosyodemorafik özellikleri değerlendirildiğinde; yaş ortalamasının $39.21 \pm 9.58$, çalışma yılının $16.12 \pm 8.61$ ve kadın doğum kliniğinde çalışma süresinin $13.17 \pm 4.61$ yıl olduğu saptanmıştır. Hemşire ve ebelerin \%88.8'inin evli, tamamının doğum yaptığı ve üniversite düzeyinde eğitim aldı̆̆ saptanmıştır. $\mathrm{Bu}$ bölümde hemşire ve ebelerin deneyimleri; "kadın doğum kliniğinde çalışan hemşire ve ebe olmayı tanımlama, kadınlara bakım verirken yaşadıkları zorluklar, yaşadığı zorluklar ile baş etme yöntemleri, yaşadıkları zorlukların ortadan kaldırılmasına ilişkin önerileri” temaları çerçevesinde verilmiş, katılımcıların alt temalara ilişkin konuşmalarından örnekler sunulmuştur.

Tema 1. Kadın doğum kliniğinde çalışan hemsirire ve ebe olmayı tanımlama

Katılımcılar doğum sonu kliniğinde çalışan hemşire ve ebe olma temasına ilişkin görüşlerini "sabır taşı", "empati", "fedakâr olma", "lider", "bakım verici/ yardımcı", "sağlık profesyoneli" ve "dikkatli olma" alt temaları altında belirtmişlerdir. Katılımcıların bazısı doğum sonu kliniğinde çalışan hemşire ve ebe olmayı "sabır taşı", "empati”, "fedakâr olma" olarak tanımlamışlardır. Bir hemşirenin bu konudaki görüşü: “... Sabırl1, özverili, empati yapabilen bir hemşire derim (K5)". Katılımcılardan bazıları doğum sonu kliniğinde çalışan hemşire ve ebe olmayı "bakım verici/ yardımcı", "sağlık profesyoneli", "lider", ve "dikkatli olma" olarak tanımlamışlardır. Bazı hemşire ve ebelerin bu konudaki görüşü: "Anne ve bebeğin tüm ihtiyaçlarına yardımcı olabilecek ve bütün sağlık gereksinimlerini karşılayabilecek sağlık profesyoneli ... (K3)”". 
“... Anneler ve aile için çok güzel bir süreç ve sizde bu süreçte ilk birkaç günde yer alıyorsunuz bu sürecin yönetimini sağlayan kişi derim (K9)”. “... Hem anne hem de bebek bizim için çok önemli ... bu nedenle bizler bu dönemde iki kat daha dikkatli olmak zorundayız ... tüm bakımlarımızda oldukça dikkatli olunması gereken bir hemşirelik dalıdır... (K7)".

Katılımcılar odak grup görüşmelerinde de benzer ifadeler kullanmışlardır. Katılımcılar, doğum sonu kliniğinde hemşire ve ebe olmayı genel olarak kadınların ve ailesinin mutluluğuna tanık olma, mutlu, verimli, özverili, fedakarlık yapmak olarak tanımlasalar da bakım verirken bazen daha fazla sabırlı olmayı, empati yapmayı gerektiren durumlarında olabildiğini belirtmişlerdir.

Katılımcılara bireysel görüşmelerde doğum sonu kliniğinde hemşire ve ebe olmayı bir şeye benzetmeleri istendiğinde "sabır taşı" (K1), "dilek ağacı" (K2), "yüksek bir dağa bayrak asmak" (K3), "geleceğe yatırım yapmak" (K4) ve "açmış gonca gül”" (K5), "anne, abla, kız kardeş" (K6), "yarış arabası" (K7), "yorgun bir savaşçı" (K8) ve "lamba" (K9) şeklinde metaforlar ortaya çıkmıştır. "Sabır taşı demek istiyorum. Çünkü siz sabır göstermezseniz ve çabalamazsanız sonuca ulaşamıyorsunuz (K1)". "Kendimi dile benden ne dilersen diyen üzerine rengarenk ipler, çaputlar bağlanmış ağaçlar gibi ama sıradan ağaçlar gibi değil. Aynı zamanda kökleriyle toprak anaya dallarıyla göğe uzanan bilgeliği temsil eden mutluluk, umut ve huzur veren ağaçlar gibi hissediyorum; dilek ağacına (K2)". "Yüksek bir dağa çıkıp bayrağı asmaya benzetiyorum. Doğum sonu gelen hastaların bütün eğitimleri verip bütün bakımlarını yapıp sonunda hastaları mutlu olarak eve gönderdiğimiz için (K3)". "Geleceğe yatırım yapmak diye düşündüm ... Doğum sonu bakım konusunda eğitim vermek geleceğe yatırım olarak düşünüyorum (K4)". "Bu serviste çalışan bir hemşireyi açmış gonca güle benzetiyorum. Çünkü doğum sonu dönemdeki hastaların kucaklarına bebeklerini aldıkları andaki sevgi yumağını görmek (K5)". "Hemşire olmak bazen anne, bazen abla yerine göre her türlü özelliğe giriyorsun. Çünkü hastanın size ihtiyacı var ... (K6)". "Yarış arabasına benzetiyorum. ... Hem annenin hem bebeğin sağlığı için hızlı olmalısınız (K7)". "Yorgun bir savaşçı gibi hissediyorum. Ne pahasına olursa olsun kadınlarımıza destek olmak onlara yardımcı olmak, bebeklerin geleceği ve bizim geleceğimiz için bu savaşı kazanmamız gerekiyor (K8)". "Işık veren bir lambaya benzetiyorum. Çünkü verdiğim bilgilerle anneyi ve aileyi aydınlatıyorum (K9)". Katılımcıların doğum sonu kliniğinde hemşire ve ebe olmakla ilgili ürettikleri metaforları genel olarak yorumlarsak; katılımcılar doğum sonu kliniğinde hemşire ve ebe olarak çalışmanın zorluklarını yansitan olumsuz metaforlar üretmenin yanı sıra kadınları bilgilendiren, yardımc1 olan ve amaca ulaşabilmek için olumlu metaforlar ürettikleri de söylenebilir.

Tema 2. Kadınlara bakım verirken yaşadıkları zorluklar

Katılımcılar doğum sonu kliniğinde çalışan hemşire ve ebe olma temasına ilişkin görüşlerini; "bebeği emzirmede/beslemede zorlanma", "iletişim sorunu", "dirençle karş1laşma/doğru bilinen yanlışlar", "kişisel hijyen yetersizliğgi", "verilen eğitimlerin geri bildiriminde sinırlılıklar", "kayıp sonrası yaşanan psikososyal sorunlar", "cinsellik ile ilgili konularda zorluk" ve "fiziksel koşulların yetersizliği" alt temaları altında belirtmişlerdir. Kat1limcilar bireysel ve odak grup görüşmelerinde en çok emzirme problemi ve iletişim sorunu olduğunu bildirmiştir. Bazı hemşire ve ebeler ise "dirençle karş1laşma/doğru bilinen yanlışlar", "kişisel hijyen yetersizliğgi", "verilen eğitimlerin geri bildiriminde sinirlılıklar" ve "fiziksel koşulların yetersizliği" olarak yaşadıkları zorluk ile ilgili deneyimlerini belirtmişlerdir. Bazı hemşire ve ebelerin bu konudaki görüşü şöyledir: "Özellikle emzirme konusunda çok sorun yaşıyoruz. Annelerin deneyimsiz olmaları, emzirme tekniğini bilmemesi,... Nasıl emzireceği ile ilişkili eğitimleri uygulamalı olarak veriyoruz ama bazı kadınlarımız emzirmek istemiyor... Sezaryen doğumlardan sonra süt bazen geç iniyor. 
Emzirmek istemeyen anneler kesinlikle emzirmiyor. Önceden kendilerini hazırlamıyorlar. Her şeyi bizden bekliyorlar... (K8)". "Prematüre doğan bebeklerin beslenmesinde çok zorlanıyoruz. Annenin deneyimsiz olması daha fazla sorun yaratıoor. Primipar olması özellikle premetüre bebeğin beslenmesinde çok sorun yaratabiliyor... (K3)"."Anne olmak istemeyenler çocuk bakımı konusunda isteksizler. Emzirmek bile onlar için iş yükü. Yapmak istemiyorlar emzirmeyi (K1)". "Emzirdiniz mi? diye sorunca hayır emzirmedim diyor. Hadi beslenmesi gerekir diyorum hemen emzirelim diyorum bunu çok s1k tekrarlayabiliyorum (K2)". "Bazen iletişim sorunu yaşayabiliyoruz. Yurt dışından (Suriyeli, vs) veya yurt içinde Türkçe bilmeyen, konuşamayan hastalarımız olabiliyor. İletişim zorluğu yaşıyoruz ... (K3)”. "Kültürel farkl11ıklar, eğitim seviyeleri bazen dil ile ilgili iletişim sorunları olabiliyor (K9)". Katılımcılardan bazıları ise "dirençle karşllaşma/doğru bilinen yanlışlar", "kişisel hijyen yetersizliği", "kayıp sonrası yaşanan psikososyal sorunlar" "verilen eğitimlerin geri bildiriminde sinırl1lıklar" "cinsellik ile ilgili konularda zorluk" ve "fiziksel koşulların yetersizliği” olarak deneyimlerini ifade etmişlerdir. Bazı hemşire ve ebelerin bu konudaki görüşleri şöyledir: "Biz ne uygularsak ne anlatırsak anlatalım hastalarımız bildiklerini okuyorlar. Davranış değişikliği yapma konusunda direnç gösteriyorlar... (K1)". "Memeyi makas yaparak emziriyorlar ... böyle olmamalı dediğinizde önceki çocuğumu ben böyle emzirmiştim diye direnç gösterebiliyorlar... (K3)". "Biz bebeğin emzirilmesi gerektiğini üzerine basa basa söylüyoruz, emzirmenin anne ve bebek için önemini anlatıyoruz ... bebeğe şekerli su verebiliyorlar ... (K6)". "Hijyen konusunda zorluklar çekiyorum. El yıkama konusunda sık sik hatırlatmak zorunda kalıyoruz ... Hijyen konusunda yetersiz olan hastalarımız oluyor (K1)". "Özellikle bebeğin kayb1 durumunda aile çok etkileniyor, tabi bizlerde, hatta uzunca bir süre etkiliyor beni ... Böyle zor bir durumda nasıl yardımcı olabileceğim konusunda çok zorlanıyorum. Kayıp yaşayan bir anne ve aile var... (K8)". "Uterus masajını öğretiyorum ama hastaların çoğu bu masajı yapmiyorlar. Unutulabiliyor. Bizlerin sürekli kontrol etmesi gerekiyor ... (K2)". "Uterus masajını yapmıyorlar özellikle gösteriyorum. Önemini vurguluyorum ama bazen yapilmıyor (K7)". "Cinsellik ile ilgili konuları konuşurken de zorlanıyorum. Nasıl söylesem diye ... Bazen hiç zamanım olmuyor bu konuyu konuşmak için klinik çok yoğun olabiliyor ... (K6)". "Fiziksel koşulların yetersizliği de bazı zorlukları yaşamamıza neden olabiliyor. Odada hasta sayısının kalabalık olması tek kişilik odaların az olması gibi. Özellikle eğitim verirken sayının çok olması dikkat dağınıklığına neden olabiliyor. Sormak istedikleri bazı soruları soramıyorlar cinsellik gibi ... (K9)”. Katılımc1lar, doğum sonu kliniğinde yaşadıkları zorlukları emzirmede, bebeğin bakımında, iletişim kurmada, önceki deneyimleri, doğru bilinen yanlışlar, genel olarak hijyen yetersizliği, eğitimlerin geri bildiriminde sınırlılıklar, kayıp sonrası yaşanan psikososyal sorunlar, cinsellik ile ilgili konularda zorluk ve fiziksel koşulların yetersizliği gibi konularda olduğunu ifade etmişlerdir. Ayrıca gebe eğitimlerine katılmayan, primapar kadınlarda özellikle bebek bakımı, beslenmesi ve diğer sorunları daha fazla yaşadıklarını belirtmişlerdir.

Tema 3. Katılımcıların yaşadiğ zorluklar ile baş etme yöntemleri

Katılımcılar doğum sonu kliniğinde çalışan hemşire ve ebe olma temasına ilişkin görüşlerini; "öğretmeye devam etmek", "sabırlı olmak", "empati yapmak", "şefkatli olmak", "pozitif olmak/güler yüzlü olmak" ve "etkili iletişim tekniklerini kullanmak" alt temaları altında belirtmişlerdir. Bireysel ve odak grup görüşmelerinde katılımcılar, "öğretmeye devam etmek" ve "sabırlı olmayl" bir baş etme yöntemi olarak belirtmiş̧ir. Bir hemşirenin bu konudaki görüşü şöyledir: "Bikmadan usanmadan anlatmaya, uygulamaya ve öğretmeye devam ediyorum... Sakin olup daha çok sabır göstermek durumundayız... (K4)". Kat1lımciların yarısından çoğu baş etme yöntemi olarak "empati yapmak", "şefkatli olmak", "pozitif 
olmak/güler yüzlü olmak" ve "etkili iletişim tekniklerini kullanmak" şeklinde ifade etmiştir. Bazı hemşire ve ebelerin görüşü: "Empati yaparak, şevkatli yaklaşarak sorunlarını çözmeye çalışıyoruz ... (K5)”, “... Pozitif olmak onları önemsemek, güler yüzle davranmak çok etkili olabiliyor... (K7)”. “... Etkili iletişim tekniklerini kullanarak onları anlamaya, iletişim kurmaya ve yardımcı olmaya çalışıyorum... (K9)". Katılımcılar, kadınlara bakım verirken yaşadıkları sorunlara ilişkin baş etme yöntemleri olarak empati yapma, şefkatli olma, sabırlı olma, güler yüzlü olma ve etkili iletişim tekniklerini kullandıkları belirtmișlerdir.

Tema 4. Doğum sonu dönemde kadınlara bakım verirken yaşanılan zorluklara ilişkin öneriler

Katılımcılar doğum sonu kliniğinde çalışan hemşire ve ebe olma temasına ilişkin görüşlerini; "özverili olma", "kapsamlı eğitim verme", "eğitime ulaştırma" ve "fiziksel koşulların iyileştirilmesi”" alt temaları altında belirtmişlerdir. Bireysel ve odak grup görüşmelerinde katılımcıların tamamına yakını, doğum sonu dönemdeki kadınlara karşı "özverili olma", "kapsamlı eğitim verme" yi çözüm önerisi olarak belirtmişlerdir. Bazı hemşire ve ebelerin bu konudaki görüşleri şöyledir: "Kendimiz biraz daha özverili olup hastalar1 cesaretlendirmeliyiz... (K3)". "Eğitimler artırılmalı. ... eğitim olmazsa olmazımız. Çok gerekli... Eğitimler gebelik, doğum ve doğum sonunu da kapsamalı ve oldukça kapsamlı eğitimler verilmeli ... (K2)". "Gebe eğitimlerinin her kesime ulaşması aynı zamanda doğum sonu bakımı kolaylaştırır. Çünkü gerçekten eğitim alarak gelen kadınlarımız daha bilinçli ve kendilerine olan güvenleri oldukça yüksek ... (K7). "Fiziksel koşulların düzenlenmesi, hem hastalarımız hem de bizlerin rahat çalışabilmesi için önemli diye düşünüyorum. Hastalarımıza daha fazla yardımcı olabiliriz, onların rahat soru sormalarına imkan sağlamış oluruz. Kalabalık ortamlarda duygu, düşünce ve sorularını bazen soramıyorlar...(K9)". Katılımc1lar, doğum sonunda bakım verirken özveri, detaylı eğitim, bu eğitimlere herkesin ulaşabilmesi, yararlanabilmesi ve fiziksel koşulların iyileştirilmesi olarak ifade edilmiştir.

\section{Tartışma}

Katılımcılara doğum sonu kliniğinde hemşire ve ebe olmayı bir şeye benzetmeleri istendiğinde "sabır taşı", "dilek ağacı", "yüksek bir dağa bayrak asmak", "geleceğe yatırım yapmak", "açmış goncagül", "anne, abla, kız kardeş", "yarış arabası", "yorgun bir savaşçı" ve "lamba" şeklinde metaforlar üretmişlerdir. Özellikle doğum sonu süreçte kadınların en yakınındaki kişiler birinci derece yakınları olan kayınvalide, anne, abla, kardeştir. Hemşire bu süreçte annelerin gereksinimi olan bakımı verdiği için ve hastasının ihtiyacı olduğunda yanında olduğunu hissettiğinden dolayı kendisini aileden birisi gibi algılamış olabilir. Doğum sonu süreçte yaşam bulgularının alınıp değerlendirilmesi, kanama takibi, epizyotomi kontrolü, bebeğin emzirilmesi gibi yapılması gereken işlemlerde hızlı olunması anne ve bebek sağlığı açısından son derece önemlidir. Hemşire anne ve bebeğe bakım verirken yapılmas1 gerekenleri tam zamanında ve eksiksiz olarak yerine getirirken kendisini yarış arabasına benzetmiş olabilir. Ebe, annelerin ihtiyacı olan bilgilerle donanımlı olduğunu hissetmesi ve bu bilgileri onlara aktarmasından dolayı kendisini lambaya benzetmiş olabilir. Hemşirelerin bilgisinden faydalanmak için annelerin, hem kendi bakımı hem de bebeğinin bakımı için bir şeyler istemesinden dolayı hemşire kendini dilek ağacına benzetmiş olabilir. $\mathrm{Bu}$ bilgileri annelere verdiğinde geleceğe yatırım yapmış olduğunu düşünmüş olabilir. Özelde kadın sağlığı genelde aile ve toplumun sağlığını sürdürmesinde etkili bir şekilde rol aldığı için geleceğe yatırım yapmış olduğunu düşünebilir. Sağlıklı anne ve bebeklerden, aileler ve toplum oluşacağı için olumlu metaforlar üretilmiş olabilir. Uzun yıllardır hemşireliğe gönül vermiş, mesleki bilgi ve donanımını hastalarının bakımı ve meslektaşlarının gelişimi için katkı sağladığından dolayı kendisini yorgun savaşçı olarak değerlendirmiş olabilir. Doğum sonu dönemde bebeğin beslenmesi oldukça 
önemlidir. Bu çalışmada doğum sonu dönemde hemşire ve ebelerin en çok yaşadıkları zorluk bebeğin emzirilmesi ve bakımıdır. Prematür bebeklerde aile ve bebeğe hastane sonrası bakım veren halk sağlığı hemşirelerinin deneyimlerine odaklanan bir çalışmada; halk sağlı̆̆ 1 hemşirelerinin prematür bebeklerin fizyolojik ihtiyaçlarını karşılamada zorluk yaşadıkları ve ailelerin özellikle prematür bebek beslenmesi ile ilgili daha fazla rehberlik taleplerinin olduğu belirlenmiştir (Currie ve ark., 2018). Prematür bebeklere bakım konusunun hemşirelerde endişeye neden olan durumlar olduğu tespit edilmiştir (Currie ve ark., 2018). Yapılan bir çalışmada; anneler genellikle bebeklerinin hastalıklarına öncelik verirken, hemşire/ebelerin ise yenidoğan beslenmesine öncelik verdikleri görülmüştür (Altunduğ ve Acar, 2011). Doğum sonu dönemde bebeğin beslenmesi oldukça önemlidir. Ülkemizde doğumların \%52'sinin sezeryan olması nedeniyle emzirme sorunları daha sik yaşanabilmektedir (TNSA 2018). Yapılan çalışmalarda sezaryenin emzirmeye başlamayı geciktirdiği, emzirme sıklığını etkileyerek bebeğin beslenmesinde ciddi sorunlara neden olabildiği belirtilmektedir (Isik ve ark., 2016; Kirca ve Adibelli 2020; Tewabe 2016).

Dil engeli sağlık hizmetlerine ulaşmada sorun olarak karşımıza çıkmaktadır. Yapılan çalışmalarda göçmen kadınların yaşadıkları ülkenin dilini bilmemesi sağlık kurumlarına ulaşma ve sağlık hizmeti almada büyük bir engel olduğu belirtilmektedir (Huang ve ark., 2012; Riggs ve ark., 2012). Bu durum hemşire/ebe ve anne arasındaki iletişimi de etkileyebilmektedir. Dolayısıyla verilecek olan bakımı da etkileyecektir (Goodwin ve ark., 2015; Knight ve ark., 2015). Bu çalışmada hemşire ve ebeler kültürel farklılıklar, eğitim seviyeleri ve dil engeli ile ilgili iletişim sorunları yaşadıklarını belirtmişlerdir. Yapılan araştırmalarda ebe/hemşirelerin göçmen kadınlarla dil, kültürel ve etnik farklılıklardan dolayı iletişim güçlüğü yaşayabilecekleri belirtilmektedir (Goodwin ve ark., 2015; Nair ve ark., 2015). Aşırı iş yükü, hemşire sayısının yetersiz olması, etkili iletişim becerilerinin kullanılmaması ve yönetici hemşirelerin bakım sürecine katılmaması, hemşirelerin hastalar ile etkili bir şekilde iletişim kurmasını olumsuz etkileyen durumlar arasında yer almaktadir (Kwake ve Petrucka, 2020). Yapılan bir çalışmada engelleri ortadan kaldırmanın ilk adımının, kültürlerarası iletişim ve sözlü çeviri hizmetlerinin yerine getirilmesi olduğu belirtilmektedir (Ikhilor ve ark., 2019). Ayrıca, sağlık profesyonellerinin kültürlerarası iletişimlerini sürekli olarak geliştirmeleri ve bunu da bakım verdikleri hastalara yansıtmaları gerekmektedir. Kurumlar, sağlık profesyonellerinin kadınların ihtiyaçlarını karşılayacak güvenli ve kültürel değerlerine uygun bakım seçenekleri sunmalıdır (Ikhilor ve ark., 2019). Bu nedenle hastanelerin yeterli sayıda donanımlı tercüman bulundurmaları gerekmektedir.

Sağlık iş gücü planlaması yapılırken, sağlık iş gücü, gerekli kaynakları ve sistemik zorlukları açıklanarak kapsamlı bir şekilde ele alınması gerektiği belirtilmektedir. Hemşirelerin, ebelerin ve kadın doğum uzmanlarının özellikle düşük ve orta gelirli bir ülkede bakım verirken karşılaştıkları kaynak zorluklarını araştırmacılar, karar vericiler ve politikacılar tarafından anlaşılması, ölüm, hastalık ve doğuma yönelik bakım konularına önemli ölçüde yarar sağlayacağı ifade edilmektedir (Macdonald ve ark., 2019). Bu çalışmada fiziksel koşulların yetersizliği yaşanılan zorluklar arasında yer almaktadır. Ülkemizde sağlık kurumlarının uygun şekilde yapılandırılmasının bu sorunların aşılmasında ve bakımın kalitesinin arttırılmasında etkili olabileceği düşünülmektedir.

Hemşireler, hasta güvenliğini sağlamada ve sağlık hizmetlerinin kalitesini yükseltmede önemli bir rol oynamaktadırlar (Flowers ve ark., 2016; Neville ve ark., 2016). Ancak, sağlık profesyonellerinin bakım verme, empati yapma ve duygusal yaklaşım gibi birçok rollerinden dolayı travmatize olma risklerinin yüksek olduğu belirtilmiştir (Sheen ve ark.,

2014). Özellikle doğum sırasında meydana gelen olaylarin olumsuz etkileri bulunmaktadır. Travmatik bir olaya tanık olmanın sonucu olarak stres meydana 
gelebilmekte ve bu ikincil travmatik stres durumu nedeniyle tükenmişlik gelişebilmektedir (Choi, 2017). Ayrıca empatik bir ilişkiye sahip olmanın da özellikle travmatik olaylara tanık olunurken, sağlık profesyonellerini duygusal yönde olumsuz etkilediği belirtilmektedir (Sheen ve ark., 2016). Hemşireler ve ebeler duygusal ve psikolojik travma açısından risk altındadırlar (Schroder ve ark., 2016; Sheen ve ark., 2014). $\mathrm{Bu}$ çalışmada hemşire ve ebeler doğum sırasında/sonrası yaşanan kayıptan dolayı psikososyal sorunlar yaşadıklarını ifade etmişlerdir. Yapılan bir çalışmada; ebelerin üçte ikisinden fazlasının travmatik bir doğum ile karşılaştığı, bu sebeple ebelerin çoğunun korku ve suçluluk duyguları yaşadıkları tespit edilmiştir (Leinweber ve ark., 2017). Başka bir çalışmada ise travmatik bir durum ile karşılaşan ebelerin, güçsüzlük, kendini sorumlu hissetme ve suçlama gibi duygular yaşadıkları görülmüştür (Rice, 2013). Perinatal kayıp ile ilgili yapılan bir çalışmada; hemşirelerin perinatal kayıp durumunda kendilerinden şüphe duydukları, hayal kırıklığı yaşadıkları ve bebeğin ölümünden dolayı başkalarını suçlama eğilimi gösterdikleri saptanmıştır (Puia ve ark., 2013). Bu çalışmanın bulguları perinatal ölümün hemşireler üzerinde uzun süreli etkisinin olabileceğini ve böyle bir travmanın sonuçları ile başa çıkmalarına yardımcı olmak için sürekli desteğe ihtiyaç duyulabileceğini göstermektedir.

Hemşireler cinsellik konusunun değerlendirilmesinin holistik bakımın ve hemşirelik işlevlerinin önemli bir yönü olduğunu kabul etmektedirler (Pınar, 2010). Ancak cinsellik konusunu ele almada yetersiz kaldıkları, isteksiz oldukları ve iletişimi başlatmada güçlük yaşadıklarını dile getirmektedirler (Haboubi ve Lincoln, 2003). $\mathrm{Bu}$ çalışmada hemşire ve ebelerin zorlandığ alanlardan birisi de doğum sonu dönemde cinsellik ile ilgili konuların nasıl anlatılacağıdır. Perinatal alanda çalışan hemşire ve ebelerin cinsellik konusu ile ilgili görüşmelerde yaşadıkları engeller ve kolaylaştırıcı faktörlerin incelendiği bir çalışmada; hemşire ve ebelerin yarısının cinsellik konusunu ele almada engeller yaşadıkları, özellikle ortamda üçüncü bir kişinin olduğu durumlarda zorlandıkları, uygun ortamın ve uygun zamanın kolaylaştırıcı bir faktör olduğu görülmüştür (Piran, 2019). Ayrıca hemşire ve ebelerin cinsellik konusu ile ilgili bilgilerini yetersiz buldukları için cinsellik konusunu yeterince değerlendiremedikleri belirtilmektedir (Olsson ve ark., 2012). Başka bir çalışmada ise hemşirelerin daha çok zaman yetersizliğinden dolayı cinsellik ile ilgili konulara değinemedikleri görülmüştür (Karaçam ve Çalışır, 2012). Ebe ve hemşirelerin cinsellikle ilgili eğitim almaları ve bu aldıkları eğitimi alana yansitmaları gerekmektedir. Bu duruma ilişkin hemşire/ebelerin cinselliği değerlendirebilecek yeterli bilgi düzeyine ulaşması cinsellikle ilgili sorunlara yönelmelerinde kolaylık sağlayacaktır.

İletişim sağlı bakım kalitesinin göstergesidir (Mohammed ve ark., 2016). Etkili iletişim hemşirenin hastayı bakıma katmasında önemli bir unsurdur (Tobiano ve ark., 2015). Bu durumda hemşirenin iletişim yeterliliği bakım davranışını etkilemektedir. Hemşireler hastanın beklentilerini dikkate almalı ve bu beklentileri karşılayacak şekilde bakım vermelidir. Hemşire tarafından sergilenen bakım davranışları hasta hemşire ilişkisinin kalitesi açısından önemlidir. Hemşirenin iletişim yeterliliği ve gereksinime yönelik verdiği bakım hemşire-hasta ilişkisinin önemli belirleyicileridir (Wiechula ve ark., 2016). Bu çalışmada hemşire ve ebeler baş etme yöntemlerini empati yapma, şefkatli olma, sabırlı olma, güler yüzlü olma ve etkili iletişim tekniklerini kullanma şeklinde belirtmişlerdir. Yapılan bir çalışmada hemşirelere verilen iletişim becerileri eğitimi sağlık profesyonellerinde olumlu davranış değişiklikleri sağlamıştır (Bays ve ark. 2014). Başka bir çalışmada hemşirelik mesleğinde iletişimin önemi bilinmesine rağmen, hemşirelerin yarısından fazlasının iletişim konusunda herhangi bir eğitim almadığ saptanmıştır (Kirca ve Bademli, 2019). 


\section{Sonuç ve Öneriler}

$\mathrm{Bu}$ çalışmada kadın doğum kliniğinde çalışan hemşire ve ebelerin doğum sonu dönemde bakım verirken emzirmede zorlanma, iletişim sorunu, kültürel farklılıklar gibi zorluklarının olduğu ve bu zorlukların ortadan kaldırılmasına ilişkin bazı öneriler sundukları belirlenmiştir. Hemşire ve ebelerin doğum sonu dönemde kadınların kültürel farklılıkları, sosyoekonomik durumları da dikkate alınarak holistik bakış açısıyla bakım verilmesi önerilir. Emzirme eğitimlerinin sürekliliğinin sağlanması, iletişim sorunları için etkili iletişim tekniklerinin kullanılması gerekirse tercümanların kullanılması önerilebilir. Annelerin kültürel farkl1lıklarına sayg1 duyulmalı ve onları yargilamadan gereken bakımın verilmesi önerilmektedir.

Araştırmanın Etik Yönü/ Ethics Committee Approval: Araştırma yapılmadan önce etik kurul onayı (Tarih: 08.01.2020/ Karar No: 64) alınmış ve hastaneden de kurum izni alınmıştır. Araştırma Helsinki Bildirgesi'nin kurallarına uyularak yapılmıştır. Hakem/Peer-review: Dış hakem değerlendirmesi.

Yazar Katkısı/Author Contributions: Fikir / kavram: NK; Tasarım: NK; Danışmanlık: NK; Veri toplama ve/veya Veri İşleme: NK; Analiz ve/veya Yorum: NK; Kaynak tarama: NK; Makalenin Yazımı: NK; Eleştirel inceleme: NK

Çıkar çatışması/Conflict of interest: Araştırmada herhangi bir çıkar çatışması yoktur.

Finansal Destek/Financial Disclosure: Araştırma için herhangi bir kurumdan maddi destek alınmamıştır.

\section{Çalışma Literatüre Ne Kattı?}

- Doğum sonu dönemde kadınlara bakım veren hemşire/ebelerin yaşadıkları zorluklar tanımlanmıştır.

- Doğum sonu dönemde kadınlara bakım veren hemşire/ebelerin yaşadıkları zorluklara yönelik çözüm önerileri sunulmuştur.

- Gelecekte yapılacak çalışmalara kaynak olması ve katkı sağlaması açısından önemlidir.

\section{Kaynaklar}

Akhavan S, Lundgren I. (2012). Midwives' experiences of doula support for immigrant women in Sweden--a Qualitative Study. Midwifery, 28(1), 80-85.

Aktaş S, Pasinlioğlu T. (2017). Ebelere verilen empati eğitiminin postpartum dönemdeki annelerin beklentilerini karşılama, doğumu ve ebeyi algilama düzeyine etkisi. Jinekoloji Obstetrik ve Neonatoloji Tıp Dergisi, 14(2), 6065.

Altunduğ K, Acar A. (2011). Doğum sonu dönemde primipar anne ve ebe/hemşirelerin eğitim önceliklerinin karşılaştırılması. Sürekli Tip Eğitim Dergisi, 20(4), 163-169.

Altuntuğ K, Ege E. (2013). Sağlık eğitiminin annelerin taburculuğa hazır oluş, doğum sonu güçlük yaşama ve yaşam kalitesine etkisi. Hemşirelikte Araştırma Geliştirme Dergisi, 15(2), 45-56.

Aslan, E. (2015). Normal lohusalık süreci ve bakım. Beji N, editör. Hemşire ve Ebelere Yönelik Kadın Sağlığı ve Hastalıkları. 1. Bask1, İstanbul, Nobel Tip Kitabevleri, s. 355-396.

Baltacı, A. (2018). Nitel araştırmalarda örnekleme yöntemleri ve örnek hacmi sorunsalı üzerine kavramsal bir inceleme. Bitlis Eren Üniversitesi Sosyal Bilimler Enstitüsü Dergisi, 7(1), 231274.

Bays AM, Engelberg RA, Back AL, Ford DW, Downey L, Shannon SE, ve ark. (2014). Interprofessional communication skills training for serious illness: Evaluation of a small group, simulated patient intervention. Journal of Palliative Medicine, 17, 159-166.

Berg M, OLafsdottir OA, Lundgren I. (2012). A midwifery model of women-centred child birth care-in Swedish and Icelandic settings. Sexual \& Reproductive Healthcare, 3(2), 79-87.

Bıkmaz Bilgen Ö, Doğan N. (2017). Puanlayıcılar aras1 güvenirlik belirleme tekniklerinin karşılaştırılması. Journal of Measurement and Evaluation in Education and Psychology, 8(1), 63-78.

Byrom S, Downe S. (2010). 'She sort of shines': midwives' accounts of 'good' midwifery and 'good' leadership. Midwifery, 26(1), 126-37.

Choi G. (2017). Secondary traumatic stress and empowerment among social workers working with family violence or sexual assault survivors. Journal of Social Work, 17(3), 358-378. 
Cioffi J. (2004). Caring for women from culturally diverse backgrounds: Midwives' experiences. Journal of Midwifery \& Women's Health, 49(5), 437-442.

Currie G, Dosani A, Premji S, Reilly S, Lodha A, Young M. (2018). Caring for late preterm infants: public health nurses' experiences. BMC Nursing, 17, 16.

Erdoğan S. (2014). Nitel Araştırmalar. Hemşirelikte Araştırma. İstanbul, Nobel Kitabevi, s. 133-164.

Flowers K, Wright K, Langdon R, McIlwrath M, Wainwright C, Johnson M. (2016). Intentional rounding: facilitators, benefits and barriers. Journal of Clinical Nursing, 25(9-10), 13461355.

Goodwin L, Hunter B, Jones, A. (2015). Immigration and continuing inequalities in maternity outcomes: Time to reexplore the client-provider relationship?. International Journal of Childbirth, 5(1), 12-19.

Güneri ES. (2013). Postpartum erken dönem kanita dayalı uygulamalar. Gümüşhane Üniversitesi Sağlık Bilimleri Dergisi, 4 (3), 482-496.

Haboubi NH, Lincoln N. (2003). Views of health professionals on discussing sexual issues with patients. Disability and Rehabilitation, 25(6), 291-296.

Hatem M, Sandall J, Devane D, Soltani H, Gates S. (2008). Midwife-led versus other models of care for child bearing women. The Cochrane Database of Systematic Reviews, (4), CD004667.

Huang YM, Merkatz R, Kang JZ, Roberts K, Hu XY, Di Donato F, et al. (2012). Postpartum unintended pregnancy and contraception practice among rural-to-urban migrant women in Shanghai. Contraception, 86(6), 731-738.

Ikhilor PO, Hasenberg G, Kurth E, Asefaw F, Pehlke-Milde J. (2019). Communication barriers in maternity care of allophone migrants: Experiences of women, healthcare professionals, and intercultural interpreters. Journal of Advanced Nursing, 75(10), 22002210.

Isik Y, Dag ZO, Tulmac OB, Pek E. (2016). Early postpartum lactation effects of cesarean and vaginal birth. Ginekologia Polska, 87, 426-430.

Karaçam Z, Çalışır H. (2012). İlk kez doğum yapan kadınlarda gebelik öncesi ve doğum sonrasi dönemlerde disparoni sıklığ durumlar. Anadolu Hemșirelik ve Sağlık Bilimleri Dergisi, 15(3), 205-213.
Kirca N, Adibelli D. (2020). Effects of the delivery type on the breastfeeding self-efficacy perception. International Journal of Caring Sciences, 13(1), 698-707.

Kirca N, Bademli K. (2019). Relationship between communication skills and care behaviors of nurses. Perspectives in Psychiatric Care, 55(4), 624-631.

Knight M, Tuffnell D, Kenyon S, Shakespeare J, Gray R, Kurinczuk JJ. (2015). Saving lives, improving mothers' care: Surveillance of maternal deaths in the UK 2011-13 and lessons learned to inform maternity care from the UK and Ireland. Confidential enquiries into maternal deaths and morbidity 2009-13. Erișim tarihi:19.06.2020,

https://www.npeu.ox.ac.uk/downloads/files/mbr race-uk/reports/MBRRACE-

UK\%20Maternal\%20Report\%202015.pdf

Kourkouta L, Papathanasiou IV. (2014). Communication in nursing practice. Materia Socio-Medica, 26(1), 65.

Kwake A, Petrucka PM. (2020). Communicaiton in nurse-patient interaction in healthcare settings in sub-Saharan Afrcia: Ascoping review. International Journal of African Nursing Sciences, 12.

Leinweber J, Creedy DK, Rowe H, Gamble J. (2017). Responses to birth trauma and prevalence of posttraumatic stress among Australian midwives. Women and birth: Journal of the Australian College of Midwives, 30(1), 40-5.

Macdonald D, Aston M, Murphy GT, Jefferies K, Mselle LT, Price S, et al., (2019). Providing postpartum care with limited resources: Experiences of nurse-midwives and obstetricians in urban Tanzania. Women and birth: Journal of the Australian College of Midwives, 32(3), 391-8.

Mohammed K, Nolan MB, Rajjo T, Shah ND, Prokop LJ, Varkey P, et al., (2016). Creating a patient-centered health care delivery system: a systematic review of health care quality from the patient perspective. American Journal of Medical Quality, 31(1), 12-21.

Nair M, Kurinczuk JJ, Brocklehurst P, Sellers S, Lewis G, Knight, M. (2015). Factors associated with maternal death from direct pregnancy complications: a UK national case-control study. BJOG: An International Journal of Obstetrics \& Gynaecology, 122(5), 653-662. 
Neville K, DiBona C, Mahler M. (2016). Validation of the nurses' perception of patient rounding scale: An exploratory study of the influence of shift work on nurses' perception of patient rounding. Orthopedic Nursing, 35(2), 84-91.

Olsson C, Berglund AL, Larsson M, Athlin E. (2012). Patient's sexuality - a neglected area of cancer nursing? The official Journal of European Oncology Nursing Society, 16(4), 426-31.

Origlia Ikhilor P, Hasenberg G, Kurth E, Asefaw F, Pehlke-Milde J, Cignacco E. (2019). Communication barriers in maternity care of allophone migrants: Experiences of women, healthcare professionals, and intercultural interpreters. Journal of Advanced Nursing, 75(10), 2200-2210.

Pinar G. (2010). Kanser tedavisi alan hastalarda cinsel disfonksiyon ve danışmanlığa ilişkin hemşirelik yaklaşımları. Gülhane Tıp Dergisi, 52(4), 241-247.

Piran M. (2019). Perinatal alanda çalışan hemşire ve ebelerin bakımda cinselliği ele alma konusunda yaşadığı engeller ve kolaylaştırıcı faktörlerin belirlenmesi [Yüksek Lisans Tezi], Ankara.

Puia DM, Lewis L, Beck CT. (2013). Experiences of obstetric nurses who are present for a perinatal loss. Journal of Obstetric, Gynecologic and Neonatal Nursing, 42(3), 321-331.

Riggs E, Davis E, Gibbs L, Block K, Szwarc J, Casey S, et al. (2012). Accessing maternal and child health services in Melbourne, Australia: Reflections from refugee families and service providers. BMC Health Services Research, 12(117), 2-16.

Schrøder K, Jørgensen j, Lamont R, Hvidt N. (2016). Blame and guilt-A mixed methods study of obstetricians' and midwives' experiences and existential considerations after involvement in traumatic childbirth. Acta Obstetricia at Gynecologica Scandinavica, 95(7), 735-745.

Sheen K, Slade P, Spiby H. (2014). An integrative review of the impact of indirect trauma exposure in health professionals and potential issues of salience for midwives. Journal of Advanced Nursing, 70(4), 729-743.

Sheen K, Spiby H, Slade P. (2016). The experience and impact of traumatic perinatal event experiences in midwives: A qualitative investigation. International Journal of Nursing Studies, 53, 61-72.
Şimşek H, Yıldırım A. (2016). Sosyal Bilimlerde Nitel Araştırma Yöntemleri. 10. Baskı, Ankara, Seçkin Yayıncılık.

Taşkın L. (2016). Postpartum Dönem. Doğum ve Kadın Sağlığı Hemşireliği. 13 Baskı, Ankara, Akademisyen Tip Kitabevi, s. 455-525.

Tewabe T. (2016). Timely initiation of breastfeeding and associated factors among mothers in Motta town, East Gojjam zone, Amhara regional state, Ethiopia, 2015: A crosssectional study. BMC Pregnancy and Childbirth, 16, 314.

Tobiano G, Bucknall T, Marshall A, Guinane J, Chaboyer, W. (2015). Nurses' views of patient participation in nursing care. Journal of Advanced Nursing, 71(12), 2741-2752.

Türkiye Nüfus ve Sağl1k Araştırması (TNSA) 2013 Ana Raporu. (2014). Hacettepe Üniversitesi Nüfus Etütleri Enstitüsü, 141-156. Erişim tarihi:12.05.2020,

http://www.hips.hacettepe.edu.tr/tnsa2013/rapor /TNSA_2013_ana_rapor.pdf

Türkiye Nüfus ve Sağlık Araştırması (TNSA) 2018 Ana Raporu. Hacettepe Üniversitesi Nüfus Etütleri Enstitüsü, 112-117. Erişim tarihi:12.05.2020,

http://www.hips.hacettepe.edu.tr/tnsa2018/rapor /TNSA2018_ana_Rapor.pdf

Uludağ E, Mete S. (2014). Doğum eyleminde destekleyici bakim. Cumhuriyet Üniversitesi Hemşirelik Dergisi, 3(2), 22-29.

Wiechula R, Conroy T, Kitson AL, Marshall RJ, Whitaker N, Rasmussen, P. (2016). Umbrella review of the evidence: What factors influence the caring relationship between a nurse and patient?. Journal of Advanced Nursing, 72(4), 723-734.

World Health Organization (WHO). (2015). Postnatal Care for Mothers and Newborns. Highlights from the World Health Organization 2013 Guidelines. Erișim tarihi:20.05.2020 https://www.who.int/maternal_child_adolescent /publications/WHO-MCA-PNC-2014Briefer_A4.pdf 